\title{
RECOGNITION OF INDUSTRIAL HERITAGE IN AGUASCALIENTES, MEXICO
}

\author{
ALEJANDRO ACOSTA COLLAZO \\ Departamento de Diseño del Hábitat, Universidad Autónoma de Aguascalientes, México
}

\begin{abstract}
In recent years, some researchers around the world have started to focus their studies on industrial heritage preservation and planning. There is an old railway station in Aguascalientes that became obsolete in 1990, but it was restored as a museum a few years ago; there is a big railway complex behind the railway station. Some of the main buildings are abandoned and an urgent reparation is needed in order to preserve this heritage for future generations. The restoration of the Locomotive Repair Building used new materials to show visitors the brand-new facilities, whilst matching the old building aspects. Also, a special soil treatment was applied to create an eco-friendly building. In addition, there are industrial mills around the railway complex, comprising the most important area of built industrial heritage in Aguascalientes city. Lately, people have started recognizing these types of buildings as part of the industrial heritage. In order to write this paper, applied statistics for a human research survey with closed questions were used. This helped discover the importance of industrial heritage for the people who live around the railway complex and next to the old factories and mills. The city planners can now identify the most important historic buildings (for the experts and for the people) and they can make an appropriate landscape architecture project. Also, it was convenient to study the typology of the old railroad houses closer to the industrial complex. It is opportune to propose an industrial heritage catalogue in the near future - studying history and examining old urban drawings - to achieve an effective sustainable urban planning in Aguascalientes.
\end{abstract}

Keywords: industrial heritage, sustainable development, city planning.

\section{INTRODUCTION}

The study of industrial heritage in Mexico is an overlooked subject, and its social recognition is very difficult. But it's not only difficult for people but also for architects and city planners. There are two historic industrial areas in Aguascalientes - defined in this paper as the railway area and the mills area. The first step in the methodology applied was to identify the persistence of the main industrial heritage buildings in these areas (see Fig. 1), even though in some cases there were only facades of industrial buildings left in the streets. The second step was to design a survey - including closed questions and a ranking question. This step in the applied methodology became a pilot survey. It was also necessary to make graphics for a demonstrative statistical analysis. Some buildings considered as part of the industrial heritage in Aguascalientes became more emblematic to the research through the survey. A residential area was identified with interesting typological aspects, as part of the landscape cohesion in the industrial heritage complex: the Ferronales Suburbs. Finally, the city planning in the areas selected should consider the citizens' opinions on possible urban physical changes and future remodelling projects.

\section{THE HISTORIC INDUSTRIAL AREAS IN EASTERN AGUASCALIENTES CITY}

The 80-hectare railroad complex is the biggest and the most important industrial heritage area of the city. In addition, there are some other old industrial buildings close to the complex: Aguascalientes Mill, Hercules Mill, San Marcos Mill, Gamba Wine Cellars, Douglas Mill and The Pearl Mill - owned by John Douglas. Also, the Ferronales Suburbs, the Heroes residential area, the Suburbs of the Station and Buenavista residential area. 


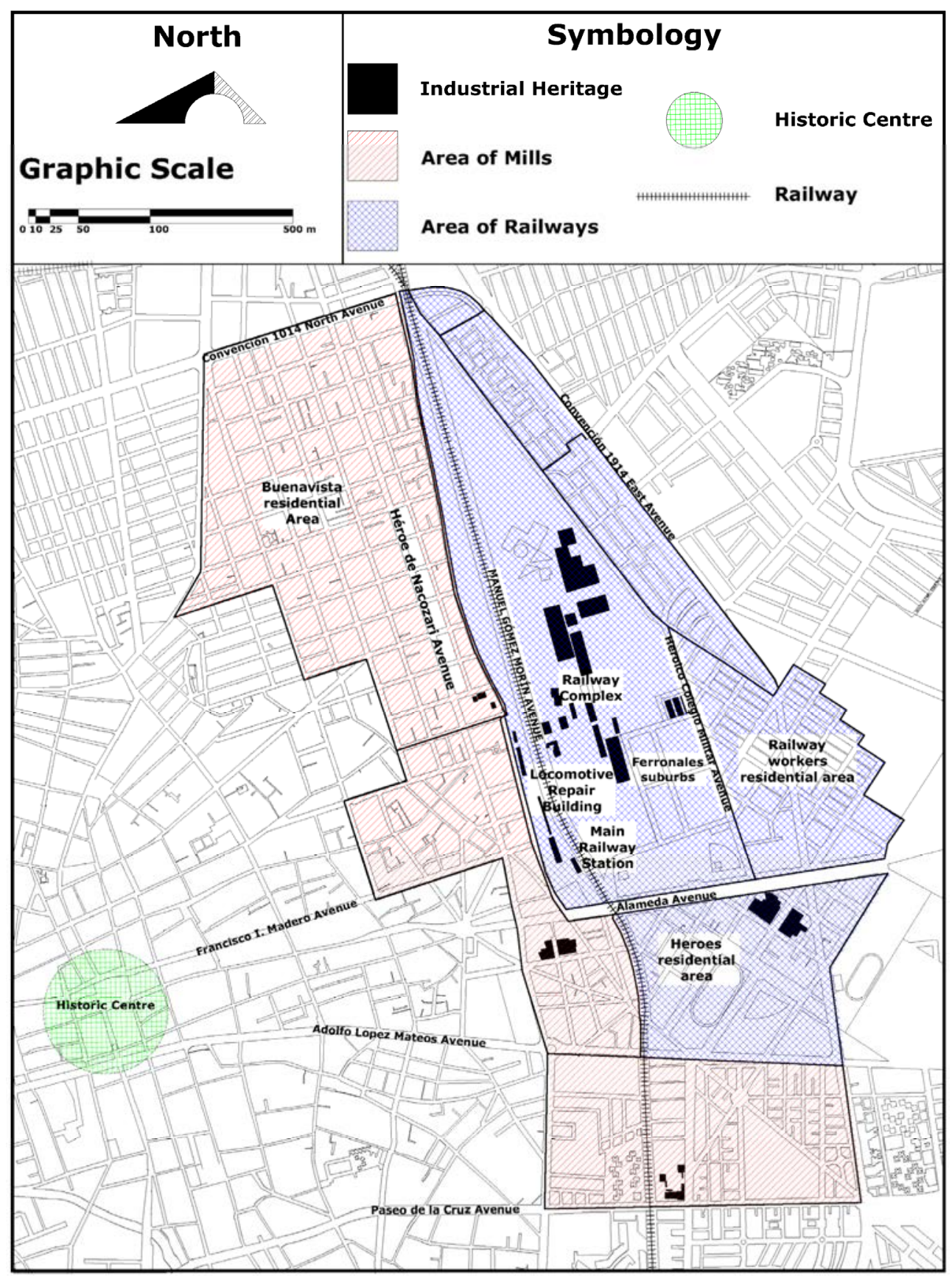

Figure 1: The main industrial areas in eastern Aguascalientes city: mills area and railways area. (Drawing: Acosta Collazo and Orenday, 2016.) 
With the purpose of making a research analysis, I defined two areas: the railways and the mills (see Fig. 1). Regards the preservation of architecture in the city, these areas are never considered; however, some buildings have been restored lately within the railway complex. It is convenient to mention here that there is a lack of interest in the study and preservation of industrial heritage in Mexico. So, many buildings of this kind are at risk of being torn down today (see Fig. 2).

\section{LANDSCAPE COHESION AND INDUSTRIAL HERITAGE}

For the sake of convenience, to approach a social construction of industrial heritage I decided to start with a basic goal: to search for landscape cohesion in the aforementioned areas - the railways and the mills - and to aim to identify the persistence of these buildings throughout time. When Poète analyses the urban land, he mentions that it contains natural artefacts as well as civic ones and they become associated with the composition of the city. In the urban composition, everything must express as faithfully as possible the particular life of the collective organism. The basis of this organism is that the city is the persistence of the plan [1]. So, the persistence of industrial heritage can be identified in actual plans and drawings, and also - as a research goal - capture people's imagery of such buildings. Even though some buildings of the industrial heritage are preserved nowadays in Mexico, some others have been torn down. Also, in some cases, only the facades persist on the streets, but behind the main facades there are new buildings. In these cases, the people's imagery of an old city continues, but the fact is that the 'inside' of the city architecture changes. It is common that old buildings become too expensive to be preserved, and owners decide to sell them or tear them down. There was a special case in Aguascalientes - the Guggenheim Smelting Co., known as the Great Smelting Central of Mexico (GFCM, acronym in Spanish). This factory completely disappeared in the city; hence, when the factory closed in 1925 they fragmented and took away every piece of the machinery and the main buildings. So, what is left of that company now? The answer is, only old photographs and news in local history journals.

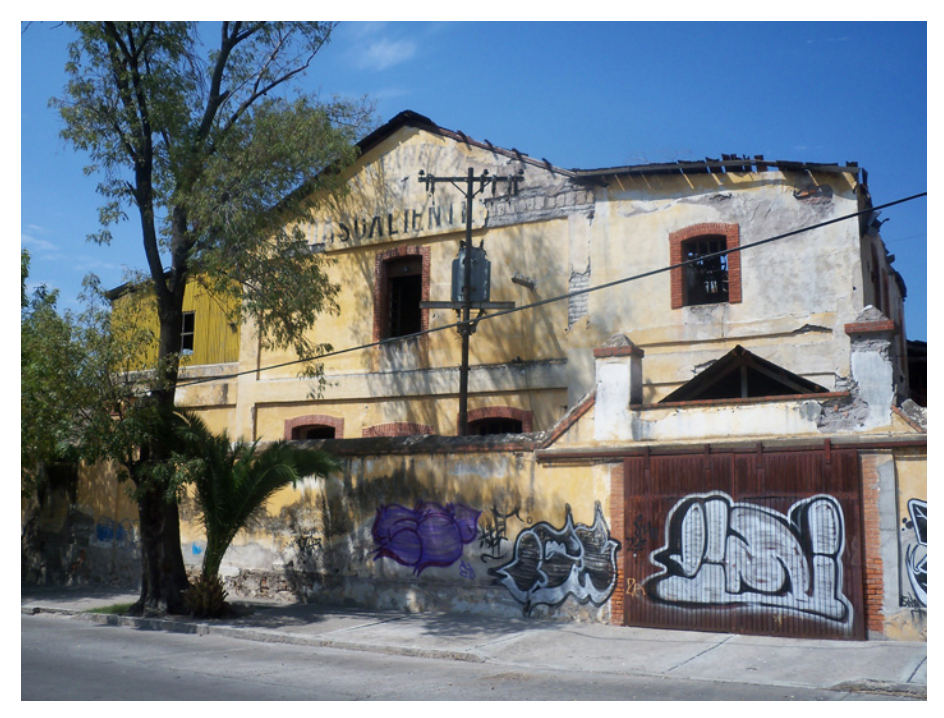

Figure 2: Aguascalientes Mill. Industrial heritage abandoned and at risk of being torn down. (Photograph: Acosta Collazo, September 2011.) 
The transition from the railway state company to private concessions of the Mexican Railway System from 1991 to 1995 brought social problems in several cities, including Aguascalientes, caused by the amount of people who were suddenly fired. The railway system in Aguascalientes was one of the most important of Latin America. In fact, this transition is considered an incongruity between landscape cohesion and industrial heritage. During those years almost every citizen in the city had familiar links with the people who used to work in the railway system. The population in Aguascalientes city is currently almost one million people.

The railway and mill areas also include industrial heritage buildings and old houses built for industrial workers. This was a typical landscape feature for Mexican cities when the railway arrived at the end of the nineteenth century and at the beginning of the twentieth century.

In order to understand landscape cohesion and industrial heritage it was necessary to design a survey, and then analyse the way people understood the industrial heritage built in the areas of the city: the railways and the mills. Fifty questionnaires were applied, using 14 closed questions and one ranking question. In the last case (question no. 15) I asked the survey respondents to compare a list of different buildings (showing photographs) to one another. The questions asked in the area of mills were:

1. Do you know what cultural heritage is?

2. Do you know which buildings are cultural heritage in the city?

3. Now, have you heard about industrial heritage?

4. Do you recognize the San Marcos Mill?

5. Do you think the San Marcos Mill is a landmark in the residential area?

6. Do you consider the San Marcos Mill as part of the cultural heritage in the city?

7. Do you think this type of buildings should be preserved?

8. Under your perspective: do you like the San Marcos Mill building?

9. Do you know something about the history of the San Marcos Mill?

10. Can you tell me if you recognize a building with similar features to the San Marcos Mill?

11. Do you think the San Marcos Mill, and some other industrial buildings - like Douglas Mill - should be considered as important historic buildings of the city?

12. Do you know if the San Marcos Mill has contributed to the urban development in the residential area (economic and social aspects)?

13. Do you know if there are museums or exhibitions around this residential area?

14. Do you think museums or exhibitions are useful or necessary for society?

15. Using a scale of $1=$ not at all important to $6=$ very important: which one of these buildings do you consider the most emblematic?

Around the area of railways, a similar methodology was used in this research, but some of the questions changed. The questionnaire applied was:

1. Do you know what cultural heritage is?

2. Do you know which buildings are cultural heritage in the city?

3. Now, have you heard about industrial heritage?

4. Do you recognize the Main Railway Station?

5. Do you think the Main Railway Station is a landmark in this context of the city?

6. Do you consider the Main Railway Station as part of the cultural heritage in the city? 
7. Do you think these types of buildings - or others, like the Locomotive Repair Building - should be preserved?

8. Under your perspective: do you like the Main Railway Station?

9. Do you know something about the history of the Main Railway Station?

10. Can you tell me if you recognize a building with similar features to the Main Railway Station?

11. Do you think the Main Railway Station, and some other industrial buildings - like Aguascalientes Mill - should be considered as an important historical building of the city?

12. Do you know if the Main Railway Station has contributed to the urban development of the residential areas around (economic and social aspects)?

13. Do you know if there are museums or exhibitions around this residential area?

14. Do you think museums or exhibitions are useful or necessary for society?

15. Using a scale of $1=$ not at all important to $6=$ very important: which one of these buildings do you consider the most emblematic?

Besides these questions, I identified for participants the groups of ages, gender, level of education and where they came from. This pilot survey allowed me to develop valuable conclusions about landscape cohesion and to understand how people perceive the industrial heritage, based on their own experiences.

\section{SOCIAL PERCEPCION OF INDUSTRIAL HERITAGE}

The results of the pilot survey - after completing 50 questionnaires in the mills area demonstrated that 36 persons knew the meaning of cultural heritage. Also, the same number of people identified the main cultural heritage in the area. The building considered as a landmark for them was the Main Railway Station. Kevin Lynch defines landmarks as point references, considered to be external to the observer - simple physical elements which may vary widely in scale. There seemed to be a tendency for those more familiar with a city to rely on it increasingly in the place of the continuities used earlier. Since the use of landmarks involves the singling out of one element from a host of possibilities, the key physical characteristic of this class is singularity - some aspect that is unique or memorable in the context. Landmarks become more easily identifiable and more likely to be chosen as significant if they have a clear form, if they contrast with their background and if there is some prominence of spatial location [2]. People can observe the Main Railway Station from a distance and also when they travel on the avenue in front of it (Manuel Gómez Morín Avenue) (see Fig. 1). The Main Railway Station is located at the heart of the industrial heritage area. But also, it's an iconic building in Aguascalientes city because of its architecture. The Locomotive Repair Building also fulfils people's definition of a significant industrial heritage area -27 people considered it to be very important. This building was restored a few years ago, but now the administrators rent the place for meetings, concerts or exhibitions. So, the building is well identified by some citizens of Aguascalientes.

Question no. 15 in the survey is a ranking question and it's about grading different industrial buildings of each area (mills or railways). The results show a preference of the people to the Main Railway Station; in second place, people prefer the Locomotive Repair Building, in third place, San Marcos Mill, and in last place, medium-sized mills and factories like: the John Douglas Mill, the Hercules Mill and the Aguascalientes Mill (see Fig. 3). Even though the San Marcos Mill isn't located in a strategic place, in the main avenues around the industrial complex the results of the survey show that it takes third place as an important building. 


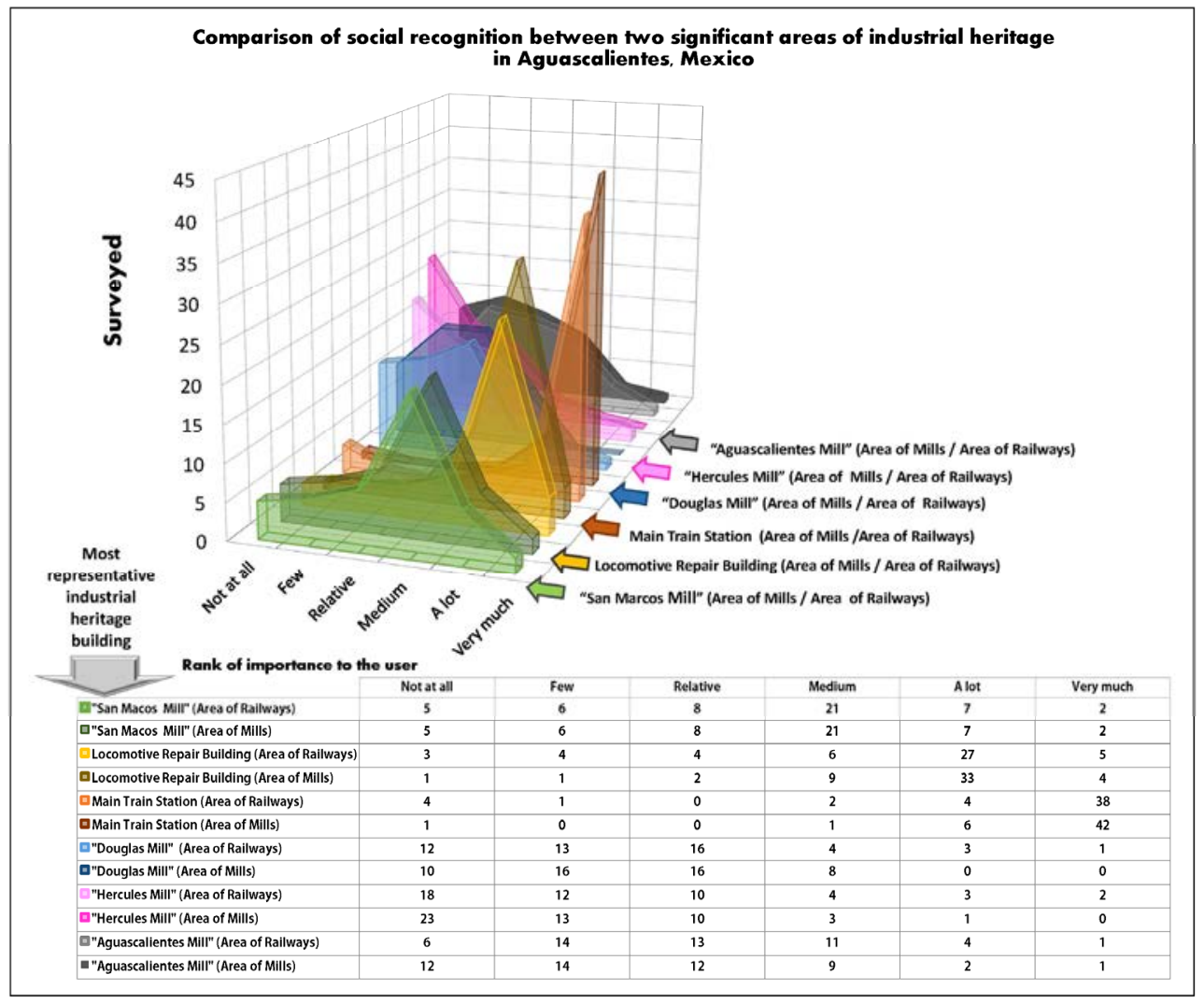

Figure 3: Recognition of industrial heritage in Aguascalientes city using ranking questions. (Drawing: Acosta Collazo and Orenday, 2016.)

I shall now discuss the information obtained from the questionnaires. Concerning gender in the mills area: 20 men and 28 women were selected and asked to answer the questions. The age rank was as follows: 4 persons aged 13-17 years old, 15 persons aged 18-35 years old, 18 persons aged 36-60 years old, and 12 persons aged $60+$. The academic level of those interviewed was as follows: 8 with primary school education, 17 with secondary school education, 12 persons with high school education and 11 with a graduate degree. No people were found to have a $\mathrm{PhD}$ degree in this area.

Thirty-six people answered that they knew the meaning of cultural heritage; they also identified some other historic buildings in the area. Thirty-eight people (out of 50) answered they hadn't heard about industrial heritage before. Thirty-seven people identified the San Marcos Mill as a landmark in the area, and 43 people think the mill should be a historic building of the city; however, 2 persons answered negatively. Regards the question of whether San Marcos Mill should be preserved: 48 people answered affirmatively and only one person said that the preservation of this building was not worthwhile.

Regards the answers to the question of whether people liked the San Marcos Mill building: 34 persons (out of 50) think the building is fine, but 15 do not like it. Regards the history of the building: 11 people mentioned that they knew it, while 38 people said they did not. 
Regarding the question of whether participants knew something relating to the history of San Marcos Mill, 36 people answered negatively and 13 people answered affirmatively. Concerning the question of whether people thought the San Marcos Mill and some other similar buildings should be considered as historic buildings in the city, 44 answered affirmatively and 5 negatively. When asked about the contribution of the San Marcos Mill to the urban development in the residential area, 30 people answered affirmatively and 19 people answered negatively. For the question no. 14 which asked if people knew there were museums about the residential area, 24 people answered affirmatively and 26 negatively; but 48 people said the museums were necessary and useful, and only 2 persons answered negatively (see Fig. 4).

After applying the survey to the area of the railways, the data obtained on gender were as follows: 17 men and 33 women; but on the other side, the groups of ages were: 3 people between 13 and 17 years old, 18 people between 18 and 35 years old, and 22 people between 36 and 60 years old. The level of education was as follows: 8 people with primary school education, 14 people with secondary school education, 14 people with high school education, 12 people with a graduate degree, and only two persons with a $\mathrm{PhD}$ degree. Forty-one interviewed people in this area knew the meaning of cultural heritage, and 9 of them did not. Also, 37 persons knew which buildings were catalogued as historic buildings, and 13 people did not. Thirty-nine people said that they had never heard about the meaning of industrial heritage, and 11 answered affirmatively.

I discovered that all the people in the area interviewed mentioned they knew well the Main Railway Station. Also, for 36 people, the station is a landmark in the area; but for 14 people it is not. Forty-nine people said they considered the Main Railway Station to be part of the cultural heritage in the city, and only one person answered negatively. Also, most of the people answered to question no. 7 that these types of buildings should be preserved. Under the perspective of 49 people interviewed, most liked the Main Railway Station and only one person answered negatively. Regards the question of whether they knew something about the history of the main railway station, 28 answered affirmatively and 22 negatively. Also, 14 people stated that they were familiar with some buildings that had similar features to the

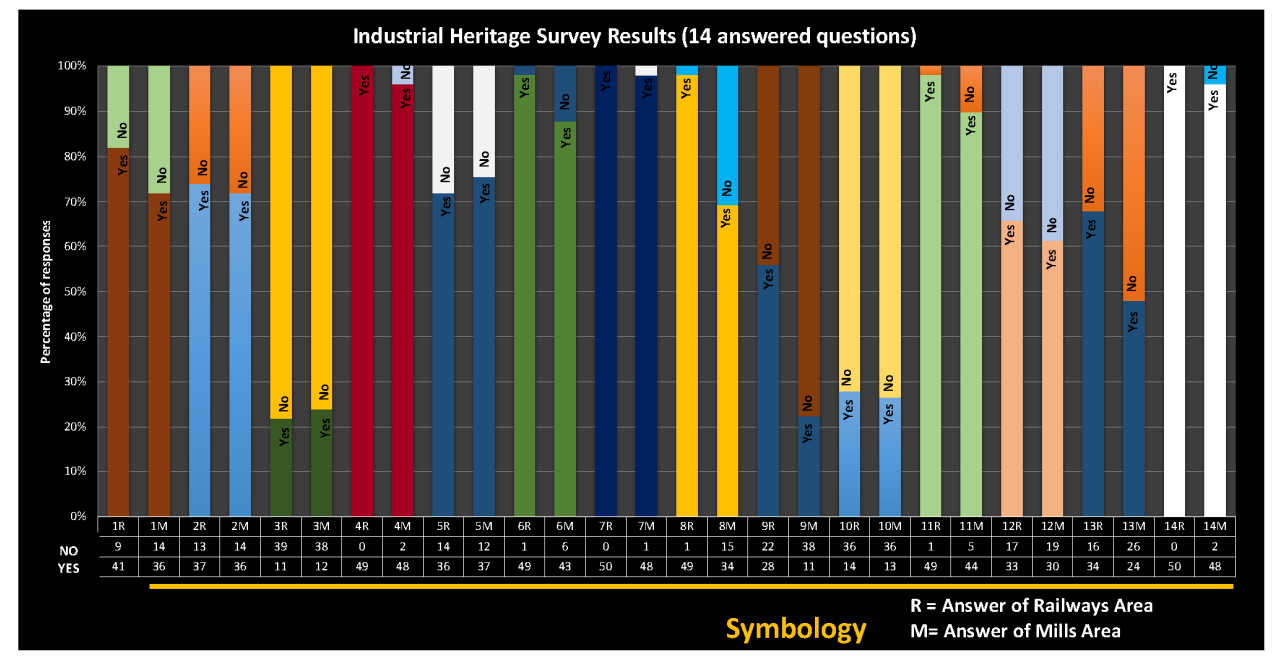

Figure 4: Percentage of responses of industrial heritage survey, in the areas: mills and railways. (Drawing: Acosta Collazo and Orenday, 2016.) 
Main Railway Station and 36 people answered negatively. Further, when I asked the participants if they thought the Main Railway Station, and some other industrial buildings, should be considered as important historical buildings of the city, 49 people answered affirmatively and only one negatively. In addition, 33 people mentioned that the Main Railway Station had contributed to the urban development of the residential areas, especially in economics and social aspects, while 17 people answered negatively. Regards question no. 14, which asked if people knew there were museums around the residential area, 34 people answered affirmatively and 16 negatively; however, all the people (50) said the museums were necessary and useful.

\section{TYPOLOGY OF THE FERRONALES SUBURBS}

After reviewing historic drawings of the city of Aguascalientes it is possible to observe the Railway Complex in the Tomas Medina Ugarte's old plan (1910) and in Arnulfo Villaseñor's old plan (1918). Also, comparing a contemporary drawing of the city with these old plans, an urban persistence of the Ferronales Suburbs can be recognized. In fact, the architecture and urbanism in the suburbs seem to be the same as the image of the place after a century and even with the same functional aspects. So, the typology, with frequent patterns in roofs, lots, construction materials and urban artefacts, make the place a singular suburb of the railway activity in Aguascalientes.

In this paper the analysis of the two areas (mills and railway areas) shows that there is a lack in landscape cohesion of industrial heritage areas and there is a risk of demolition for some of them. It is easy to identify the buildings that are abandoned. But in the Ferronales Suburbs there is still cohesion in their architecture and urbanism, especially when speaking of the typological aspects and quotidian life.

The front porches of the houses in the Ferronales Suburbs are still original (see Fig. 5), even though they look more like American front porches. This is because the main railway administrators were Americans and these houses were built for them. With the arrival of the automobile to the city, places like the Ferronales Suburbs became obsolete. There are effects of the cars in several residential areas of the city, but in the Ferronales Suburbs it looks like time has not passed by after one hundred years.

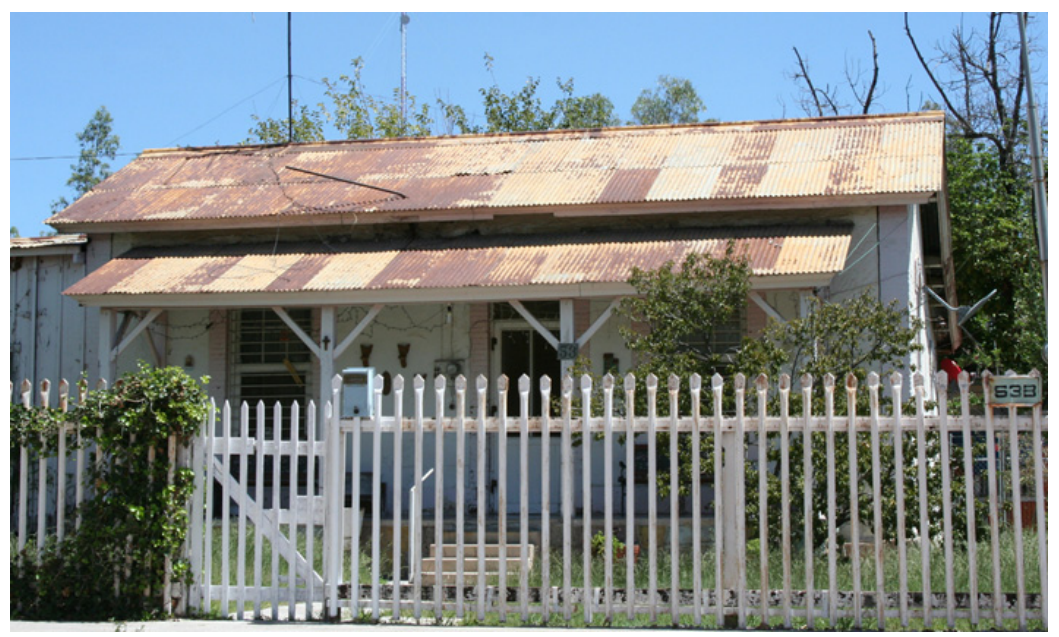

Figure 5: The front porches of the houses in the Ferronales Suburbs are still original. (Photograph: Acosta Collazo, July 2015.) 


\section{CONCLUSIONS}

In the study of industrial heritage there are legal holes at the local level. This situation affects the preservation of some buildings of this kind in the city of Aguascalientes. The main federal law that protects historic buildings in Mexico - authorized in 1972 - does not include industrial heritage. This is a risk for the preservation of important buildings in this category. The residential areas and the Ferronales Suburbs that surround the Railway Complex are important for an understanding of the local culture, specially when speaking of urbanism and architecture - as well as the history of architecture of Aguascalientes city. The importance of the typology of the houses in the Ferronales Suburbs is not only about architecture, but quotidian life. This place shows a contrast with contemporary architecture in the city. Patterns of materials, the streets designs and some urban artefacts make it an exceptional place in Aguascalientes.

Social interpretation of industrial heritage was very important for this paper. Urban planning in Mexico needs to include the citizens' opinions on possible urban changes to historic places. If society is integrated with their opinions about changes in historic places, city planning could become more efficient. The use of questionnaires can be a useful research tool to interpret opinions about remodelling projects [3]. The survey applied in this research about industrial heritage demonstrated that people should be more informed about which ones are the main buildings included in the industrial heritage of the city. In fact, there is not a complete catalogue of these types of buildings and complexes in the whole city of Aguascalientes. But some iconic buildings - like the Main Railway Station - were clearly identified by people (see Fig. 6). Restoration activities in the city should consider landscape cohesion and industrial heritage - and not focus their attention on only preserving specific buildings. And of course, there would be better results if city planners and architects considered the opinions of people, to find out more about image perceptions and the way people use open spaces.

The results of this paper demonstrate that there should be landscape cohesion in urbanism, and such cohesion should be included in the sustainable development and planning of the city. Otherwise, more industrial heritage will be torn down in the near future.

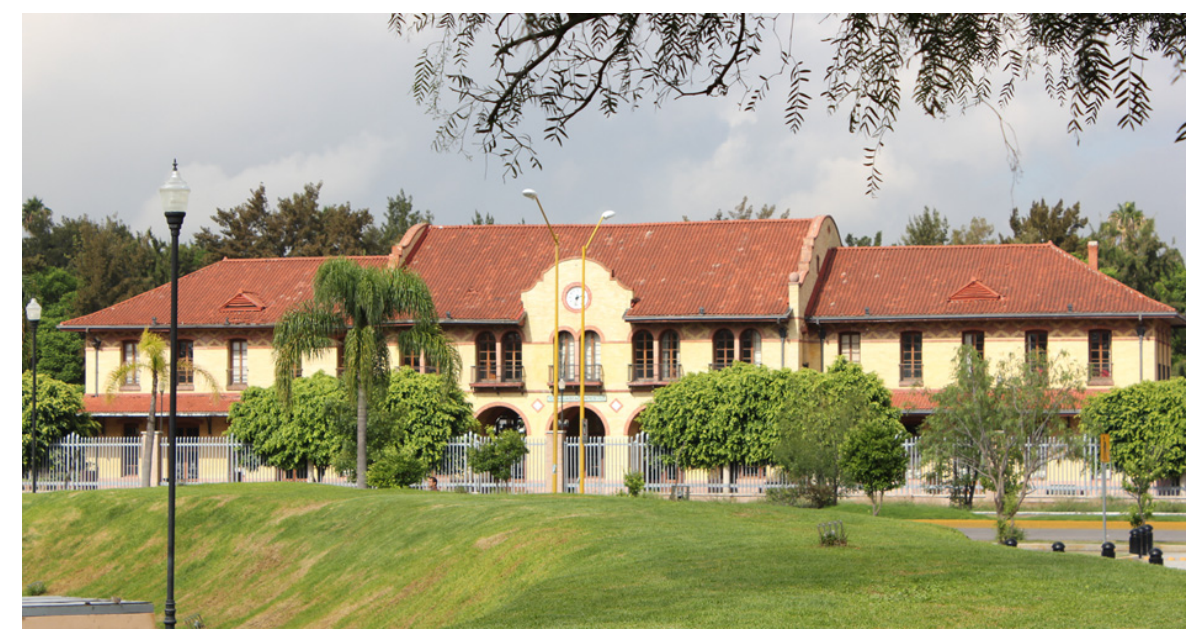

Figure 6: Main façade of the Main Railway Station in Aguascalientes, Mexico. (Photograph: Acosta Collazo, July 2015.) 
416 Sustainable Development and Planning IX

\section{REFERENCES}

[1] Rossi, A., The Architecture of the City, The Graham Foundation for Advanced Studies in the Fine Arts, Chicago, The Institute for Architecture and Urban Studies, New York, and MIT Press: New York and London, p. 51, 1984.

[2] Lynch, K., The Image of the City, MIT Press: USA, pp. 78-79, 1960.

[3] Acosta Collazo, A., Historic preservation in Aguascalientes, Mexico: urban regeneration, new corporate centralities and sustainability. Structural Studies, Repairs and Maintenance of Heritage Architecture XIV, eds C.A. Brebbia \& S. Hernández, WIT Press: UK, p. 131, 2015. 